\title{
Short Communication: Estimation of the above- and below-ground carbon stocks in University of Lampung, Indonesia
}

\author{
IRWAN SUKRI BANUWA`, RIZKI AFRILIYANTI, MUHAJIR UTOMO, SRI YUSNAINI, MELYA RINIARTI, \\ PURBA SANJAYA, ERDI SUROSO, WAHYU HIDAYAT ${ }^{\vee \varphi}$ \\ Faculty of Agriculture, Universitas Lampung. Jl. Sumantri Brojonegoro No. 1 Bandar Lampung 35145, Lampung, Indonesia. Tel.: +62-721-701609. \\ Fax.: +62-721-702767, `email: irwanbanuwa@yahoo.comwahyu.hidayat@fp.unila.ac.id
}

Manuscript received: 4 December 2018. Revision accepted: 14 February 2019

\begin{abstract}
Banuwa IS, Afriliyanti R, Utomo M, Yusnaini S, Riniarti M, Sanjaya P, Suroso E, Hidayat W. 2019. Short Communication: Estimation of the above- and below-ground carbon stocks in University of Lampung, Indonesia. Biodiversitas 20: 676-681. University of Lampung in Indonesia has been promoting green campus program since 2004 to meet environmental goals, including specific targets for energy and $\mathrm{CO}_{2}$ reductions. This study was conducted to establish baseline data on the carbon stock and carbon sequestered in the campus of University of Lampung in order to support the program. The above-ground carbon stocks were estimated from tree biomass, understory biomass, and litters, while under-ground carbon stocks were measured by determining the organic carbon in soil. The results showed that the average above-ground carbon stock was 35.65 t.ha $^{-1}$, consisted of 35.10 t.ha ${ }^{-1}, 0.18$ t.ha $^{-1}$, and 0.12 t.ha ${ }^{-1}$ from trees biomass, understory biomass, and litters, respectively. The average below-ground carbon stock was 317.33 t.ha $^{-1}$ and the $\mathrm{CO}_{2}$ uptake by plants was 130.74 t.ha $^{-1}$. The Faculty of Agriculture with the largest area of green open space contributed to the highest carbon stocks and carbon sequestration, while the Faculty of Medicine showed the lowest values. The results could be essential to suggest the climate change mitigation effort, such as the expansion and optimization of green spaces area.
\end{abstract}

Keywords: Above ground carbon; below ground carbon, biomass, carbon sequestration, green space, soil organic carbon

\section{INTRODUCTION}

Greenhouse gases consist of condensing greenhouse gases (i.e., water vapor and stratiform clouds) and noncondensing greenhouse gases (i.e., carbon dioxide $\left(\mathrm{CO}_{2}\right)$, methane $\left(\mathrm{CH}_{4}\right)$, nitrous oxide $\left(\mathrm{N}_{2} \mathrm{O}\right)$, ozone $\left(\mathrm{O}_{3}\right)$, and chlorofluorocarbons (CFCs)) (Lacis et al. 2010). Among such gases, $\mathrm{CO}_{2}$ is the most important greenhouse gas that plays the most significant role in global warming due to its higher radiative forcing than the other greenhouse gases that emitted from the human activities (Forster et al. 2007). In addition, Lacis et al. (2010) revealed that $\mathrm{CO}_{2}$ is the single most important climate-relevant greenhouse gas in Earth's atmosphere because the gas does not condense and precipitate from the atmosphere at current climate temperatures, whereas water vapor can and does.

Human activities that could reduce atmospheric $\mathrm{CO}_{2}$ are needed to decrease the effects of global warming. Kyoto Protocol urgently suggested two different actions for reducing $\mathrm{CO}_{2}$ emissions such as through the reduction of human activities related to greenhouse gas emission and the establishment and development of carbon sinks in the biosphere by tree plantation (Bipal and Mrinmo 2010; Aguirre-Salado et al. 2014). Trees play an important role in reducing $\mathrm{CO}_{2}$ by absorbing and accumulating it in their leaves, branches, stems, and roots as biomass (McPherson and Simpson 1999). Biomass has been widely used for carbon cycle studies because it is an important indicator of vegetation growth and dynamic (Yan et al. 2013).
Trees in urban green spaces such as in university, can provide many benefits to urban dwellers such as lowering temperature, providing shade, aesthetic beauty, mitigating air pollution, reducing noise, giving shelter of diverse birds and other species, and sequester particulate matter (Nagendra and Gopal 2010; Nowak et al. 2013). In addition to these ecosystem services, urban green space also plays an important role in sequestering atmospheric $\mathrm{CO}_{2}$ through photosynthesis. University of Lampung (Unila) in Indonesia has been promoting green campus program since 2004 to meet environmental goals, including specific targets for energy and $\mathrm{CO}_{2}$ reductions. According to the green campus metric (UI GreenMetric World University Ranking 2018), Unila was ranked 20 among universities in Indonesia and is making efforts to manage and improve its sustainability by reducing carbon footprint and thus help combat global climate change.

In the context of global carbon research, many studies have been conducted in the ecosystems outside the urban areas such as in natural forest, afforested and reforested forests (Murdiyarso et al. 1994; Kindermann et al. 2008; Aguirre-Salado et al. 2014). Recently, several studies also revealed that urban green spaces are rich in biodiversity and could store a considerable amount of carbon in aboveand belowground (Myeong et al., 2006; Zhao et al., 2010; Nagendra and Gopal 2011; Syamani et al. 2012; Nowak et al. 2013). In our previous works, we have reported the amount of carbon stock and $\mathrm{CO}_{2}$ plant uptake in the Integrated Field Laboratory of Faculty of Agriculture, 
University of Lampung (Banuwa et al. 2016). To provide a comprehensive result, this study determines the net aboveand below-ground accumulation of carbon in University of Lampung to provide baseline data for the improvement of the green campus program. We compare our results with the available data of rates of carbon uptake by other universities in Indonesia.

\section{MATERIALS AND METHODS}

\section{Study area}

The study was conducted in University of Lampung, Bandar Lampung City, Lampung Province, Indonesia. The study area has a tropical climate, with relative humidity of $60 \%$ to $85 \%$, and temperature of $23{ }^{\circ} \mathrm{C}$ to $37^{\circ} \mathrm{C}$. The annual precipitation is ranging between 2,257 to $2,454 \mathrm{~mm} /$ year, with high rainfall occurs from December to April. The sampling area was divided into the area of: 1. Other purposes area (OA), 2. Faculty of Agriculture (FA), 3. Faculty of Engineering (FE), 4. Faculty of Economics and Business (FEB), 5. Faculty of Social and Political Sciences (FSPS), 6. Faculty of Law (FL), 7. Faculty of Teacher Training and Education (FTTE), 8. Faculty of Mathematics and Natural Sciences (FMNS), and 9. Faculty of Medicine (FM) (Figure 1).

\section{Procedures}

Field data were collected through physical measurement, field observation, and laboratory analysis. The above-ground carbon stocks were estimated from tree biomass, understory biomass, and litters, while underground carbon stocks were measured by determining the total organic carbon in soil.

\section{Sampling plot}

In each observation area, census method was used for tree biomass measurement. The sampling plots for destructive sampling of understory plants (i.e., shrubs, herbs, and grasses) were $1 \mathrm{~m} \times 1 \mathrm{~m}$, while litters used sampling plots of $0.5 \mathrm{~m} \times 0.5 \mathrm{~m}$ (Hairiah et al. 2011). The sampling plots were selected using a stratified random sampling method. The total number of sample plots was 140 which was distributed as follow: 56 in OA, 25 in FA, 18 in FE, 6 in FEB, 3 in FSPS, 4 in FL, 14 in FTTE, 10 in FMNS, and 5 in FM.
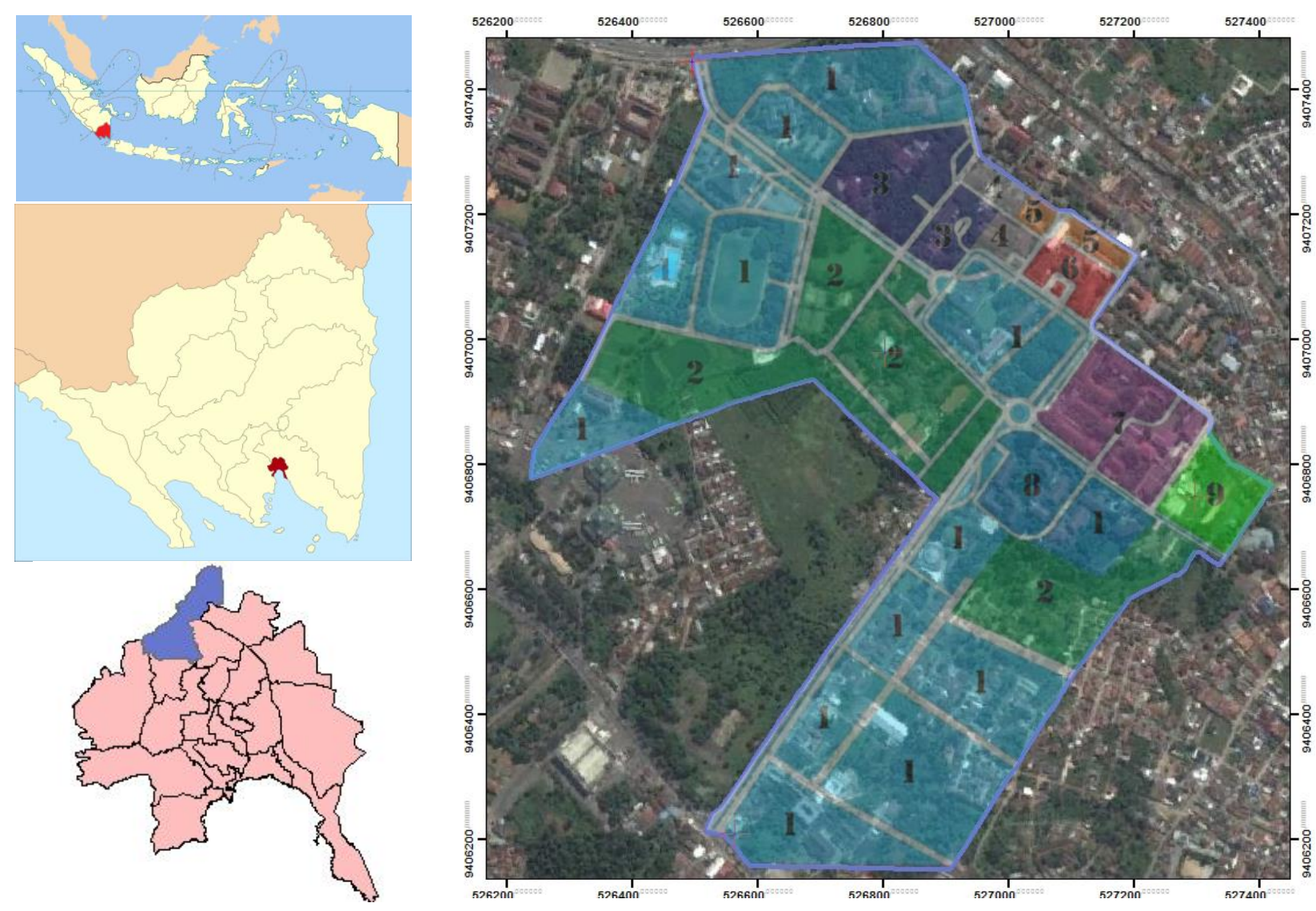

Figure 1. The study area in the campus of University of Lampung: 1. Other purposes area (OA), 2. Faculty of Agriculture (FA), 3. Faculty of Engineering (FE), 4. Faculty of Economics and Business (FEB), 5. Faculty of Social and Political Sciences (FSPS), 6. Faculty of Law (FL), 7. Faculty of Teacher Training and Education (FTTE), 8. Faculty of Mathematics and Natural Sciences (FMNS), and 9. Faculty of Medicine (FM) 
Table 1. Estimation of tree biomass using allometric equations

\begin{tabular}{lll}
\hline Description & $\begin{array}{l}\text { Estimation of tree } \\
\text { biomass }(\mathrm{g} / \text { tree) }\end{array}$ & Reference \\
\hline Branched tree & $\mathrm{DW}=0.11 \rho \mathrm{D}^{2.62}$ & Ketterings (2001) \\
Non-branched tree & $\mathrm{DW}=\pi \rho \mathrm{H} \mathrm{D}^{2} / 40$ & Hairiah et al. (1999) \\
Albizia & $\mathrm{DW}=0.0272 \mathrm{D}^{2.831}$ & Sugiharto (2002) \\
Pine & $\mathrm{DW}=0.0417 \mathrm{D}^{2.6576}$ & Waterloo (1995) \\
Coffee (pruned) & $\mathrm{DW}=0.281 \mathrm{D}^{2.06}$ & Arifin (2001) \\
Banana & $\mathrm{DW}=0.030 \mathrm{D}^{2.13}$ & Arifin (2001) \\
Bamboo & $\mathrm{DW}=0.131 \mathrm{D}^{2.28}$ & Priyadarsini (2000) \\
Necromass & $\mathrm{DW}=\pi \rho \mathrm{H} \mathrm{D}^{2} / 40$ & $\begin{array}{l}\text { Hairiah and Rahayu } \\
\end{array}$ \\
\end{tabular}

Note: DW: dry weight (g), D: diameter at breast height $(\mathrm{cm}), \rho$ : density $\left(\mathrm{g} / \mathrm{cm}^{3}\right), \mathrm{H}$ : height $(\mathrm{m})$

\section{Biomass measurement}

To estimate tree biomass, diameter at breast height (DBH) and height of each tree were measured in each sampling area. Three measurements were conducted for each tree. Tree diameter was measured at $1.3 \mathrm{~m}$ above the ground using diameter tape. Tree height was measured using a digital laser rangefinder (Bosch DLE 70 Professional) based on the geometric relationship between triangles. Allometric relations from tree diameter and height were used to estimate the biomass of woody plants (Table 1).

The understory plants were taken from each sampling plot by cutting the entire above-ground portion of a plant, while litters were picked up from the soil surface. The freshly collected understory plants and litters samples were then weighed to determine its fresh weight. A subsample (a species or a type) of the understory plants and litters of about $100 \mathrm{~g}$ were oven-dried at $80^{\circ} \mathrm{C}$ for about $24-48 \mathrm{~h}$ until reaching constant weight (Roberts et al. 1985) and then weighed. Biomass of each species or type of understory plants and litters was calculated using following equation (Hairiah et al. 2011):

Dry weight of biomass $(g)=\frac{\text { Oven dry weight of subsample }(g) \times \text { Total fresh weight }(g)}{\text { Fresh weight of subsample }(g)}$

\section{Organic carbon determination}

The content of organic carbon in biomass and soil were analyzed using a method reported by Walkley and Black (1934). Sample with a dry weight of $0.03 \mathrm{~g}$ was treated with $5 \mathrm{ml}$ of potassium dichromate solution $\left(\mathrm{K}_{2} \mathrm{Cr}_{2} \mathrm{O}_{7}\right)$ followed by the addition of $10 \mathrm{ml}$ of concentrated sulfuric acid $\left(\mathrm{H}_{2} \mathrm{SO}_{4}\right)$. The mixture was gently swirled and left at room temperature in a fume hood for 12 hours. After the mixture was cooled, $100 \mathrm{ml}$ of distilled water, $5 \mathrm{ml}$ of $\mathrm{H}_{3} \mathrm{PO}_{4}, 2.5 \mathrm{ml}$ of $\mathrm{NaF} 4 \%$ and 5 drops of diphenylamine indicator were added into the suspension. After that, the suspension was titrated with the standard $0.2 \mathrm{~N}$ ferrous ammonium sulfate $\left(\mathrm{Fe}\left(\mathrm{NH}_{4}\right)_{2}\left(\mathrm{SO}_{4}\right) * 6 \mathrm{H}_{2} \mathrm{O}\right)$ solution into a final color change of light green. One $\mathrm{ml}$ of $0.2 \mathrm{~N}$ ferrous ammonium sulfate is equivalent to the $0.009807 \mathrm{~g}$ of $\mathrm{K}_{2} \mathrm{Cr}_{2} \mathrm{O}_{7}$ or $0.0006 \mathrm{~g}$ of carbon. Organic carbon content in the sample was calculated as:
Organic carbon $(\%)=\frac{(B-S) \times 0.0006}{m} \times 100$

Where: B is the volume of ferrous solution used in the blank titration, $S$ is the volume of ferrous solution used in the sample titration, $\mathrm{m}$ is the mass of the sample in gram used in the analysis.

\section{Carbon stock and $\mathrm{CO}_{2}$ uptake estimation}

The carbon stock was calculated from the data of organic carbon content using the equation (Hairiah and Rahayu 2007):

Carbon stock $\left(t h a^{-1}\right)=\frac{\text { Organic carbon }(\%) \times \text { Dry weight of biomass }(g)}{\text { Site area }(\text { ha })}$

The $\mathrm{CO}_{2}$ uptake was calculated from the data of carbon stock using following equation:

$$
\text { CO } \mathrm{O}_{2} \text { uptake }\left(\mathrm{t} \cdot \mathrm{ha} \mathrm{a}^{-1}\right)=\frac{\mathrm{MrCO}_{2} \times \text { Carbon stock }\left(\mathrm{t} . h \mathrm{a}^{-1}\right)}{\mathrm{ArC}}
$$

Where: $\mathrm{Mr} \mathrm{CO}_{2}$ is the molecular weight of $\mathrm{CO}_{2}$ (44) and $\mathrm{ArC}$ is atomic weight of $\mathrm{C}$ (12).

\section{Data analysis}

The results of biomass measurement and carbon stock estimation were statistically analyzed using an SPSS 17 software package. Analysis of variance (ANOVA) was carried out using a significance level of 0.05 after verifying the additivity (Tukey's test) and homogeneity of variance (Bartlett's test) of the data.

\section{RESULTS AND DISCUSSION}

\section{Plant biomass}

The results revealed that the area of FA contained the highest value of biomass than the other areas of University of Lampung, showing a total biomass of $256.43 \mathrm{t}^{\mathrm{h}} \mathrm{ha}^{-1}$ that was dominated by tree biomass of 254.12 t.ha ${ }^{-1}$, while understory and litters biomass were only $1.61 \mathrm{t}^{-h^{-1}}$ and 0.69 t.ha $^{-1}$, respectively (Table 2). There were 4818 trees grow in the area of University of Lampung. The trees consisted of 87 species with the most frequent and dominant species were: Swietenia macrophylla of 657 trees, Lagerstroemia Linnaeus of 228 trees, Filicium decipiens of 172 trees, Tectona grandis of 147 trees, Dalbergia latifolia of 141 trees, Mangifera indica of 132 trees, Syzygium polyanthum of 109 trees, Falcataria moluccana of 107 trees, Peltophorum pterocarpum of 91 trees, and Peronema canescens of 84 trees. The measurement of small, medium, and large trees (sapling, pole, and sawlog stands) showed that the area of OA had the highest number of trees planted of 1,643 trees (34.10\%), followed by the area of FA of 981 trees (20.36), FTTE of 617 trees $(12.74 \%)$, FE of 477 trees $(9.73 \%)$, FMNS of 461 trees $(9.57 \%)$, FM of 243 trees $(5.04 \%)$, FEB of 121 trees $(2.51 \%)$, FL of 200 trees $(4.15 \%)$, and FSPS of 86 trees $(1.78 \%)$. Although number of trees in the area of OA was higher than FA, the area of FA had a higher 
number of large trees or sawlog stands (trees with DBH of more than $20 \mathrm{~cm}$ ) of 370 trees $(31.57 \%)$ than the area of OA of 272 trees $(23.21 \%)$, thus resulted in the area of FP to have a highest value of tree biomass. Kinderman et al. (2008) stated that tree is the main component of forest ecosystems that contain the absolute quantity of the living biomass, constitute more than $80 \%$ of the total forest biomass. Syam'ani et al. (2012) also stated that the tree component has the highest percentage of biomass because it has stem that is functioned to store the photosynthesis products for the growth.

The area of FA has tree density of more than 100 trees/ha, which is the highest density compared to the other areas. According to Banuwa (2013), the amount of biomass in different land-use depends on the diversity and density of the existing plants. Understory biomass in FA was significantly higher compared to the other areas with the exception for the values of understory biomass in the area of FL and FSPS, showing no significant differences. The area of FM showed the lowest tree biomass of 37.29 t.ha $^{-1}$, FMNS showed the lowest understory biomass of 0.17 t.ha ${ }^{1}$, and FSPS showed the lowest litter biomass of 0.08 t.ha ${ }^{-1}$. The area of FM showed the lowest total biomass of 38.40 t.ha $^{-1}$ due to small number of tree plantation and density.

The average value of tree biomass in University of Lampung of 76.75 t.ha ${ }^{-1}$ was higher compared to the results in another university in Indonesia (Lavista et al. 2016), showing an estimated value of tree biomass in Bogor Agricultural University of 58.22 t.ha ${ }^{-1}$. However, the result was lower than the estimated value of tree biomass in University of Indonesia of 345.72 t.ha ${ }^{-1}$ (Lubis et al. 2013).

\section{Above-ground carbon stock}

The above-ground carbon stocks were calculated by multiplying the value of each biomass (Table 2) and the organic carbon content of each biomass. Table 3 showed that the organic contents of tree biomass were ranging between $42.52-48.76 \%$, understory biomass was 13.56 $32.30 \%$, and litters biomass were $12.50-33.33 \%$. The estimation of carbon stock in University of Lampung revealed that the area of FA had the highest above-ground carbon stock than the other areas with the total carbon stock of 116.91 t.ha $^{-1}$, derived mainly from trees. The carbon stock in the area of FA almost similar the value of carbon stock in tropical forests of 161-300 t.ha ${ }^{-1}$ (Murdiyarso 1994). The lowest value was observed in the area of FM with the total carbon stock of 17.83 t.ha $^{-1}$. However, the results of analysis of variance (ANOVA) showed no significant difference with the amount of carbon sequestered in the area of FL and FEB (Table 3). The results showed that the average carbon stock in University of Lampung of 35.65 t.ha ${ }^{-1}$ was higher than that estimated in Bogor Agricultural University and Srengseng urban forest in Jakarta of 27.36 t.ha $^{-1}$ and 24.04 t.ha-1, respectively (Lavista et al. 2016; Lubis et al. 2013).

The value of carbon stock in plant strongly correlated with the amount of biomass in the plants, particularly tree biomass. According to Banuwa et al. (2016), tree biomass is the largest contributor of carbon due to its higher level of carbon storage when compared to seasonal crops. Plants absorb large quantity of atmospheric carbon dioxide $\left(\mathrm{CO}_{2}\right)$ by photosynthesis which then converted into oxygen $\left(\mathrm{O}_{2}\right)$ that emitted back to the surrounding environment and glucose $\left(\mathrm{C}_{6} \mathrm{H}_{12} \mathrm{O}_{6}\right)$ for its growth, while the excess of food was stored as biomass.

\section{Below-ground carbon stock}

The below-ground carbon stock in this study was estimated through the soil organic carbon (SOC). SOC is an important parameter for the environmental status estimation of terrestrial that mainly derived from the decomposition of plants and animals or anthropogenic sources such as chemical contaminants, fertilizers or organic-rich waste (Avramidis et al. 2015). The result revealed that the highest SOC was observed in the area of FA, which then resulted in the highest soil carbon stock of 46.67 t.ha $^{-1}$. The value of SOC and soil carbon stock in OA showed similar results with those observed in FA, showing a SOC of $2.08 \%$ and an estimated soil carbon stock of 41.60 t.ha $^{-1}$. The lowest SOC of $1.40 \%$ was observed in the area of FM with the estimated soil carbon stock of 27.93 t.ha ${ }^{-1}$ (Table 4). However, the results of statistical analysis showed no significant difference in the value of soil carbon stocks between the areas in University of Lampung, Indonesia.

Table 2. Plant biomass in University of Lampung, Indonesia

\begin{tabular}{llcccc}
\hline \multirow{2}{*}{ Site } & \multirow{2}{*}{ Area (ha) } & \multicolumn{4}{c}{ Plant Biomass (t.ha $\left.\mathbf{A}^{\mathbf{1}}\right)$} \\
\cline { 3 - 6 } & & Tree & Understory & Litters & Total \\
\hline FA & 10.00 & $254.12^{\mathrm{A}}(4.70)$ & $1.61^{\mathrm{A}}(0.65)$ & $0.69^{\mathrm{A}}(0.05)$ & $256.43^{\mathrm{A}}(5.19)$ \\
FE & 7.20 & $67.55^{\mathrm{C}}(3.17)$ & $0.20^{\mathrm{E}}(0.13)$ & $0.79^{\mathrm{A}}(0.09)$ & $68.55^{\mathrm{D}}(3.06)$ \\
FEB & 2.50 & $39.05^{\mathrm{G}}(3.29)$ & $0.57^{\mathrm{CD}}(0.24)$ & $0.10^{\mathrm{CD}}(0.07)$ & $39.74^{\mathrm{G}}(2.95)$ \\
FL & 1.50 & $41.72^{\mathrm{F}}(2.47)$ & $1.23^{\mathrm{AB}}(0.43)$ & $0.13^{\mathrm{CD}}(0.05)$ & $43.09^{\mathrm{F}}(3.48)$ \\
FMNS & 3.90 & $76.98^{\mathrm{B}}(2.95)$ & $0.17^{\mathrm{E}}(0.04)$ & $0.66^{\mathrm{A}}(0.04)$ & $77.82^{\mathrm{C}}(5.17)$ \\
FTTE & 5.60 & $52.89^{\mathrm{D}}(3.61)$ & $0.53^{\mathrm{D}}(0.05)$ & $0.33^{\mathrm{B}}(0.14)$ & $53.76^{\mathrm{E}}(3.68)$ \\
FSPS & 1.00 & $44.18^{\mathrm{E}}(3.70)$ & $1.18^{\mathrm{AB}}(0.62)$ & $0.08^{\mathrm{D}}(0.05)$ & $45.45^{\mathrm{F}}(3.04)$ \\
FM & 2.10 & $37.29^{\mathrm{H}}(5.21)$ & $0.97^{\mathrm{BC}}(0.35)$ & $0.13^{\mathrm{C}}(0.05)$ & $38.40^{\mathrm{G}}(2.75)$ \\
OA & 22.50 & $76.93^{\mathrm{B}}(2.83)$ & $0.21^{\mathrm{E}}(0.23)$ & $0.80^{\mathrm{A}}(0.19)$ & $82.49^{\mathrm{B}}(2.79)$ \\
Average & & 76.75 & 0.74 & 0.41 & 78.41 \\
\hline
\end{tabular}

Note: Means within a column followed by the same capital letter are not significantly different at 5\% significance level using least significant difference (LSD) test. Numbers in parentheses are standard deviations. FA: Faculty of Agriculture, FE: Faculty of Engineering, FEB: Faculty of Economics and Business, FL: Faculty of Law, FMNS: Faculty of Mathematics and Natural Sciences, FTTE: Faculty of Teacher Training and Education, FSPS: Faculty of Social and Political Sciences, FM: Faculty of Medicine, and OA: other purposes area 
Table 3. Carbon stocks in University of Lampung, Indonesia

\begin{tabular}{|c|c|c|c|c|c|c|c|}
\hline \multirow[t]{2}{*}{ Site } & \multicolumn{3}{|c|}{ C-organic (\%) } & \multicolumn{3}{|c|}{ Carbon stock (ton/ha) } & \multirow[b]{2}{*}{ Total } \\
\hline & Tree & Understory & Litters & Tree & Understory & Litters & \\
\hline \multirow[t]{2}{*}{$\overline{\text { FA }}$} & 45.72 & 32.30 & 27.54 & $116.19^{\mathrm{A}}$ & $0.52^{\mathrm{A}}$ & $0.19^{\mathrm{B}}$ & $116.91^{\mathrm{A}}$ \\
\hline & $(2.42)$ & (3.98) & $(2.36)$ & $(2.15)$ & $(0.25)$ & $(0.02)$ & $(2.36)$ \\
\hline \multirow[t]{2}{*}{ FE } & 45.76 & 30.00 & 26.58 & $30.91^{\mathrm{D}}$ & $0.06^{\mathrm{C}}$ & $0.21^{\mathrm{AB}}$ & $31.19^{\mathrm{D}}$ \\
\hline & $(5.03)$ & (7.33) & (9.48) & $(1.45)$ & (0.03) & (0.09) & (1.45) \\
\hline \multirow[t]{2}{*}{ FEB } & 46.17 & 22.81 & 20.00 & $18.03^{\mathrm{G}}$ & $0.13^{\mathrm{C}}$ & $0.02^{\mathrm{D}}$ & $18.19^{\mathrm{G}}$ \\
\hline & $(4.02)$ & $(13.56)$ & $(8.49)$ & $(1.36)$ & $(0.06)$ & $(0.01)$ & $(1.39)$ \\
\hline \multirow[t]{2}{*}{ FL } & 42.52 & 24.39 & 15.38 & $17.74^{\mathrm{GH}}$ & $0.30^{\mathrm{AB}}$ & $0.02^{\mathrm{D}}$ & $18.07^{\mathrm{G}}$ \\
\hline & $(1.09)$ & (7.55) & $(1.95)$ & $(1.40)$ & $(0.02)$ & $(0.01)$ & $(1.41)$ \\
\hline \multirow[t]{2}{*}{ FMNS } & 44.41 & 29.41 & 33.33 & $34.19^{\mathrm{C}}$ & $0.05^{\mathrm{C}}$ & $0.22^{\mathrm{AB}}$ & $34.47^{\mathrm{C}}$ \\
\hline & $(4.90)$ & $(5.58)$ & (5.93) & $(2.31)$ & $(0.02)$ & $(0.03)$ & $(2.27)$ \\
\hline \multirow[t]{2}{*}{ FTTE } & 44.64 & 26.42 & 30.30 & $23.61^{\mathrm{E}}$ & $0.14^{\mathrm{C}}$ & $0.10^{\mathrm{C}}$ & $23.86^{\mathrm{E}}$ \\
\hline & (1.99) & $(11.78)$ & $(8.99)$ & $(1.73)$ & $(0.10)$ & $(0.07)$ & $(1.68)$ \\
\hline \multirow[t]{2}{*}{ FSPS } & 45.59 & 13.56 & 12.50 & $20.14^{\mathrm{F}}$ & $0.16^{\mathrm{C}}$ & $0.01^{\mathrm{D}}$ & $20.32^{\mathrm{F}}$ \\
\hline & $(4.98)$ & $(5.78)$ & $(1.05)$ & $(1.64)$ & $(0.04)$ & $(0.00)$ & $(1.66)$ \\
\hline \multirow[t]{2}{*}{ FM } & 47.04 & 25.77 & 23.08 & $17.54^{\mathrm{H}}$ & $0.25^{\mathrm{BC}}$ & $0.03^{\mathrm{D}}$ & $17.83^{\mathrm{G}}$ \\
\hline & $(4.29)$ & $(8.42)$ & (2.69) & $(1.16)$ & $(0.18)$ & $(0.01)$ & $(1.24)$ \\
\hline \multirow[t]{2}{*}{$\mathrm{OA}$} & 48.76 & 23.81 & 31.25 & $37.51^{\mathrm{B}}$ & $0.05^{\mathrm{C}}$ & $0.25^{\mathrm{A}}$ & $40.03^{\mathrm{B}}$ \\
\hline & $(1.23)$ & $(4.51)$ & $(7.81)$ & $(1.35)$ & $(0.03)$ & $(0.04)$ & $(2.75)$ \\
\hline Average & 45.62 & 25.38 & 24.44 & 35.10 & 0.18 & 0.12 & 35.65 \\
\hline
\end{tabular}

Notes: Means within a column followed by the same capital letter are not significantly different at 5\% significance level using least significant difference (LSD) test. Numbers in parentheses are standard deviations. FA: Faculty of Agriculture, FE: Faculty of Engineering, FEB: Faculty of Economics and Business, FL: Faculty of Law, FMNS: Faculty of Mathematics and Natural Sciences, FTTE: Faculty of Teacher Training and Education, FSPS: Faculty of Social and Political Sciences, FM: Faculty of Medicine, and OA: other purposes area

The area of FA and OA has more tree vegetation than the other areas, hence a major amount of soil organic matters could be produced. Post and Kwon (2000) showed that land use and vegetation affect SOC by influencing soil respiration, carbon flux, and fixation of carbon within soil and deeper substratum. Furthermore, the authors stated that the important factors and processes that determine the direction and rate of change in SOC content when vegetation and soil management practices changed include: (i) increasing the input rates of organic matter; (ii) changing the decomposability of organic matter inputs that increase LF-OC; (iii) placing organic matter deeper in the soil either directly by increasing below-ground inputs or indicrectly by enhancing surface mixing by soil organisms; and (iv) enhancing physical protection through intraaggregate or organomineral complexes. Management practices also affecting the SOC, i.e., the least amount of soil disturbance contributes a positive effect on SOC accumulation, while increasing the intensity of cultivation results in lower SOC and a greater proportion associated with the fine size fractions (Bajracharya et al. 1998).

\section{$\mathrm{CO}_{2}$ uptake}

The results showed the highest and the lowest $\mathrm{CO}_{2}$ uptake by plants in the FA and FM with the respective values of 428.69 t.ha ${ }^{-1}$ and 65.39 t.ha ${ }^{-1}$ (Figure 2). The area of FL and FEB with the respective values of 66.28 t.ha $^{-1}$ and 66.69 t.ha $^{-1}$ showed similar amount of $\mathrm{CO}_{2}$ uptake than that observed in FM. The average $\mathrm{CO}_{2}$ uptake by plants in University of Lampung was $130.74 \mathrm{t}^{-h^{-1}}$. The result was higher than the average $\mathrm{CO}_{2}$ uptake in Srengseng urban forest in Jakarta of $88.15 \mathrm{t}^{-h a^{-1}}$, but lower than that estimated in University of Indonesia of 634.40 t.ha $^{-1}$ (Lubis et al. 2013).
Table 4. Soil organic carbon (SOC) and soil carbon stock in University of Lampung, Indonesia

\begin{tabular}{lll}
\hline Site & $\begin{array}{l}\text { SOC } \\
(\mathbf{\%})\end{array}$ & $\begin{array}{l}\text { Soil carbon stock } \\
\text { (t.ha' }^{-1} \text { ) }\end{array}$ \\
\hline FA & $2.33(0.49)$ & $46.67(9.72)$ \\
FE & $1.88(1.44)$ & $37.67(20.87)$ \\
FEB & $1.78(1.07)$ & $35.60(21.47)$ \\
FL & $1.45(0.10)$ & $29.00(2.08)$ \\
FMNS & $1.66(0.14)$ & $33.20(2.70)$ \\
FTTE & $1.71(0.14)$ & $34.20(2.88)$ \\
FSPS & $1.57(0.43)$ & $31.47(8.56)$ \\
FM & $1.40(0.55)$ & $27.93(10.92)$ \\
OA & $2.08(0.46)$ & $41.60(9.24)$ \\
Average & 1.76 & 35.26 \\
\hline Notes
\end{tabular}

Notes: Numbers in parentheses are standard deviations. FA: Faculty of Agriculture, FE: Faculty of Engineering, FEB: Faculty of Economics and Business, FL: Faculty of Law, FMNS: Faculty of Mathematics and Natural Sciences, FTTE: Faculty of Teacher Training and Education, FSPS: Faculty of Social and Political Sciences, FM: Faculty of Medicine, and OA: other purposes area

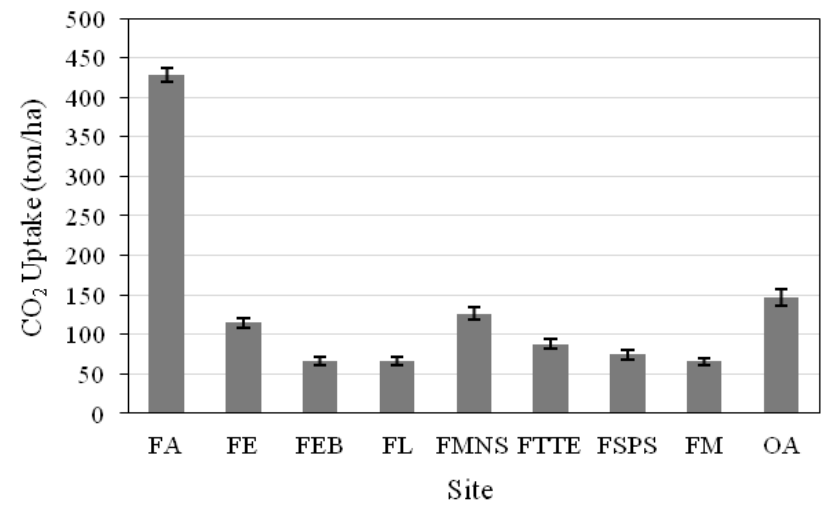

Figure 2. $\mathrm{CO}_{2}$ uptake in the University of Lampung, Indonesia 
In conclusion, the result showed that the green space in University of Lampung has a significant role for carbon sequestration, beside its role for biodiversity conservation, filtering dust and pollutants from the air, creating cooler urban areas, and providing an outlet for outdoor recreation their positive effect on air quality. The positive effect of urban forests and trees on air quality is expected to improve human health by removing gaseous air pollutants and particulate matter. To achieve the expected goal as well as contributing to mitigating climate change, the expansion and optimization of green spaces area are one of the important means in urban development plans. The estimated above- and below-ground carbon stocks in University of Lampung suggested that the site with the largest area of green space yielded the highest carbon stocks and carbon sequestered. The average above-ground carbon stock was $35.65 \mathrm{t}^{-h^{-1}}$ which consisted of $35.10 \mathrm{t}$. $\mathrm{ha}^{-1}, 0.18 \mathrm{t}^{-h a^{-1}}$, and $0.12 \mathrm{t}^{-h^{-1}}$ from trees biomass, understory biomass, and litters, respectively. The average soil carbon stock was $35.26 \mathrm{t}^{-h^{-1}}$. The average carbon sequestered was 130.74 t.ha $^{-1}$. Tree plantation in the areas with a relatively low amount of carbon stock and sequestered is needed to optimize the existing green space areas.

\section{REFERENCES}

Avramidis P, Nikolaou K, Bekiari V. 2015. Total organic carbon and total nitrogen in sediments and soils: a comparison of the wet oxidationtitration method with the combustion-infrared method. Agric Agricult Sci Procedia 4: 425-430

Aguirre-Salado CA, Treviño-Garza EJ, Aguirre-Calderón OA, JiménezPérez J, González-Tagle MA, Valdéz-Lazalde JR, Sánchez-Díaz G, Haapanen R, Aguirre-Salado AI, Miranda-Aragón L. 2014. Mapping aboveground biomass by integrating geospatial and forest inventory data through a k-nearest neighbor strategy in North Central Mexico. J Arid Land 6 (1): 80-96.

Bajracharya RM, Lal R, Kimble JM. 1998. Soil organic carbon distribution in aggregates and primary particle fractions as influenced by erosion phases and landscape position. In: Lal R, Kimble J, Follett R, Stewart BA (eds), Soil Processes and the Carbon Cycle. CRC Press, Boca Raton, FL.

Banuwa IS. 2013. Erotion. Kencana Publishing. Jakarta.

Banuwa IS, Mutiasari T, Buchari H, Utomo M. 2016. Carbon Stock in Integrated Field Laboratory, Faculty of Agriculture, University of Lampung. J Trop Soils 21 (2): 91-97.

Bipal J, Mrinmoy M. 2010. Impact of Climate Change on Natural Resource Management. Springer, Netherland.

Forster P, Ramaswamy V, Artaxo P, Berntsen T, Betts R, Fahey DW, Haywood J, Lean J, Lowe DC, Myhre G, Nganga J, Prinn R, Raga G, Schulz M, van Dorland R. 2007. Changes in Atmospheric Constituents and in Radiative Forcing. In: Solomon S, Qin D, Manning M, Chen Z, Marquis M, Averyt KB, Tignor M, Miller HL (eds.). Climate Change 2007: The Physical Science Basis. Contribution of Working Group I to the Fourth Assessment Report of the Intergovernmental Panel on Climate Change. Cambridge University Press, Cambridge, UK.
Hairiah K, Sitompul SM, Van Noordwijk M, Palm C. 2001. Methods for Sampling Carbon Stocks Above and Below Ground. World Agroforestry Centre (ICRAF), SEA Regional Office, Bogor.

Hairiah K, Rahayu S. 2007. Pengukuran 'karbon tersimpan' di berbagai macam penggunaan lahan. Bogor. World Agroforestry Centre ICRAF, SEA Regional Office, University of Brawijaya, Malang. [Indonesian]

Hairiah K, Dewi S, Agus F, Velarde S, Ekadinata A, Rahayu S, van Noordwijk M. 2011. Measuring Carbon Stocks Across Land Use Systems: A Manual. World Agroforestry Centre (ICRAF), SEA Regional Office, Bogor, Indonesia.

Kindermann GE, McCallum I, Fritz S, Obersteiner M. 2008. A global forest growing stock, biomass and carbon map based on FAO Statistics. Silva Fennica 42: 387-396.

Lacis AA, Schmidt GA, Rind D, Ruedy RA. 2010. Atmospheric $\mathrm{CO}_{2}$ : Principal control knob governing earth's temperature. Science 330: 356-359.

Lavista L, Prasetyo LB, Hermawan R. 2016. Dynamics change of the above carbon stocks in Bogor Agricultural University, Darmaga Campus. Procedia Environ Sci 33: 305-316.

Lubis SH, Arifin HS, Samsoedin I. 2013. Tree carbon stock analysis of urban forest landscape in DKI Jakarta. J For Socio-Econ Res 10 (1): $1-20$.

McPherson EG, Simpson JR. 1999. Carbon dioxide reduction through urban forestry: Guidelines for professional and volunteer tree planters. In: USDA Forest Service, PSW General Technical Report. No. PSW-GTR-171. Albany, CA, USA.

Murdiyarso M, Hairiah K, van Noordwijk M. 1994. Modelling And Measuring Soil Organics Matter Dynamics And Greenhouse Gas Emmision After Forest Conversion. Report of a Workshop Training Course, Bogor 8-15 August 1994.

Myeong S, Nowak DJ, Duggin MJ. 2006. A temporal analysis of urban forest carbon storage using remote sensing. Rem Sens Environ 101: 277-282.

Nagendra H, Gopal D. 2011. Tree diversity, distribution, history, and change in urban parks. Urban Ecosyst 14: 211-223.

Nowak DJ, Greenfield EJ, Hoehn RE, Lapoint E. 2013. Carbon storage and sequestration by trees in urban and community areas of the United States. Environ Poll 178: 229-236.

Post WM, Kwon KC. 2000. Soil carbon sequestration and land-use change: Processes and potential. Global Ch 6: 317-327.

Roberts MJ, Long SP, Tieszen LL, Beadle CL. 1985. Chapter 1: Measurement of Plant Biomass and Net Primary Production. In: Coombs J, Hall DO, Long SP, Scurlock JMO (eds.). Techniques in Bioproductivity and Photosynthesis. 2nd ed. Pergamon Press, New York.

Syam'ani AR, Agustina, Susilawati, Nugroho Y. 2012. Above Ground Carbon Stocks on Various Land Cover Systems in Amandit Sub Watershed. J Trop For 13 (2): 148-58.

Ussiri DAN, Lal R. 2017. Carbon Sequestration for Climate Change Mitigation and Adaptation. Springer, Dordrecht.

Walkley A, Black IA. 1934. An examination of degtjareff method for determining soil organic matter and a proposed modification of the chromic acid titration method. Soil Sci 37: 29-37.

Weber C. 2013. Ecosystem services provided by urban vegetation: a literature review. In: Rauch S, Morrison G, Norra S et al. (eds.). Urban Environment. Springer, Dordrecht.

Yan F, Wu B, Wang YJ. 2013. Estimating aboveground biomass in $\mathrm{Mu}$ Us Sandy Land using Landsat spectral derived vegetation indices over the past 30 years. J Arid Land 5 (4): 521-530.

Zhao M, Kong Z, Escobedo FJ, Gao J. 2010. Impacts of urban forests on offsetting carbon emissions from industrial energy use in Hangzhou, China. J Environ Manag 91: 807-813. 